\title{
Testing and Analysis of Drinking Water Quality in the Rural Areas of High-tech District in Tai'an City
}

\author{
Wu-yuan Jia \\ Agro-ecology \& Environment Key Lab, Shandong Agricultural University \\ Tai'an 271000, Shandong, China \\ $\&$ \\ School of Chemistry and Chemical Engineering, Taishan Medical University \\ Tai'an 271016, Shandong, China \\ Chuan-rong Li \\ Agro-ecology \& Environment Key Lab, Shandong Agricultural University \\ Tai'an 271000, Shandong, China \\ Kun Qin \& Lin Liu \\ School of Chemistry and Chemical Engineering, Taishan Medical University \\ Tai'an 271016, Shandong, China
}

\begin{abstract}
In order to understand the sanitation condition of drinking water in the rural areas of High-tech District in Tai'an City, and to provide scientific bases for drinking water quality improvement and public health protection, water quality was tested and analyzed using the methods recommended in the China national health standard GB5750-85, which included 14 indicators, i.e. sensory characteristics, general chemical indicators, toxicological indicators and bacteriological indicators. The results showed that the contents of total coliform, ammonia nitrogen and iron exceeded the standards, and the contents of volatile phenol and $\mathrm{Cr}$ (VI), and the total hardness slightly exceeded the standards. It was concluded that drinking water, especially well water in the rural areas of High-tech District in Tai'an City was slightly polluted. Therefore, currently the related government departments should focus on strengthening "the three wastes" treatment and sanitation management of drinking water transmission, and providing additional water disinfection facilities.
\end{abstract}

Keywords: Drinking water, Water quality testing, Indicators

\section{Introduction}

Water is a limited natural resource, which is essential for human survival. Water resources that met certain water quality standards are needed in industrial and agricultural production, as well as in many aspects of people's lives. Domestic water, in particular, is closely related to people's lives, and its quality directly affects public health. Tai' an City is the political, economic and cultural center of central Shandong Province, and in the past 50 years its urban population has surged, its urban area has expanded, and its industrial wastewater and sewage discharge have increased rapidly. As a result, the groundwater pollution has become more and more serious in Tai'an, and in some regions the groundwater contaminants have seriously exceeded the standards (Lu \& Wang, 2009). In Tai'an, $60 \%$ of the urban water supply comes from groundwater. Since the late 1970's, because of the rapid urban development, industrial and domestic water usage has increased year by year, underground water has been overexploited for years, and the groundwater environment has showed the trend of degradation (Wang et al, 2009). To ensure drinking water safety, to identify and eliminate the water pollution factors, we tested and analyzed the drinking water quality in rural areas of Hi-tech District in Tai'an.

\section{Materials and methods}

Water quality surveillance stations were set up in 16 villages, including Dingjiahonggou Village, Shihuikuan Village, Tuo'ao Village etc. in High-tech District of Tai'an. At each station, in April (dry season) and August (raining season) of 2008, tap water and well water (with three repetitions) were tested and analyzed using the 
methods recommended in Standard Examination Methods for Drinking Water (2001) and Sanitary Standards for Drinking Water (2001). The test indicators included sensory characteristics, eight general chemical indicators (color, turbidity, taste and odor, total dissolved solids, $\mathrm{pH}$, total hardness, iron and volatile phenol), four toxicological indicators ( $\mathrm{Cr}(\mathrm{VI})$, fluoride, nitrate and ammonia nitrogen) and two bacteriological indicators (total bacteria and total coliform).

\section{Results and analysis}

A total of 96 samples of tap water and well water from 16 villages were tested and analyzed, in which three sensory characteristics and general chemical indicators did not meet the national sanitary standards, two toxicological indicators and two bacteriological indicators exceeded the standards. The results were in Table 1.

As shown in Table 1, in general, drinking water in High-tech District of Tai'an met the Sanitary Standard for Drinking Water (GB5750-85) in terms of sensory characteristics and general chemical indicators. Only two water samples exceeded the total hardness standard, with an exceeding rate of $12.5 \%$, and seven water samples exceeded the iron content standard, with an exceeding rate of $43.8 \%$. In the toxicological tests, four water samples exceeded the $\mathrm{Cr}$ (VI) content standard, with an exceeding rate of $25 \%$, and the ammonia nitrogen content exceeding rate was $75 \%$, which indicated that the drinking water in the rural areas of High-tech District has been polluted by bacteria, sewage or animal feces. In addition, in the bacteriological tests, two water samples exceeded the total bacteria standard, with an exceeding rate of $12.5 \%$, and nearly $70 \%$ of the water samples exceeded the total coliform standard, which indicated that the drinking water in the rural areas of High-tech District has been contaminated to different degrees by intestinal bacteria, such as Salmonella, Shigella, Vibrio, and intestinal virus, and are potentially hazardous to public health.

\section{Discussions and suggestions}

Through the tests, it was found that the major contaminants in drinking water were coliform and ammonia nitrogen, followed by volatile phenol and iron, which indicated that the drinking water in High-tech District has been subject to different levels of pollution. Therefore, in the future, the related government departments need to strictly implement drinking water disinfection measures and regularly monitor drinking water quality, so that full compliance with the Sanitary Standards for Drinking Water issued by Chinese government will be realized. In High-tech District of Tai'an, there are many wells, but water from most wells is directly consumed without disinfection. In addition, some of the wells are in low-lying locations and with serious infiltration, and there are no protection facilities around the wells, therefore the hygiene conditions are poor, and dirt on the ground can easily penetrate into the wells. Although in most areas of High-tech District centralized water supply is adopted, but the management system is still not perfect, and most related government departments do not conduct water quality testing. When drinking water network was under renovation, the pipelines buried underground were relatively close to the ground and susceptible to external pressure or tillage, therefore secondary pollution caused by rupture sometimes took place. In addition, currently iron pipes and galvanized pipes are mostly used for transporting drinking water. As time passes, such pipes are easily rusted and the galvanized layer may peel off to cause metal go into water, which affects the water quality and taste, or has adverse effects on public health in the long run. As a result, the following suggestions were made:

(1) Water purification and disinfection need to be enhanced, and additional water disinfection facilities should be provided. No matter ground water or surface water is used as the source of drinking water, water body need to be disinfected, disinfection management need to be strengthened, and disinfection quality need to be improved.

(2) The locations of self-built wells should be chosen carefully, and locations with low elevation or close to sources of pollutions should be avoided. In addition, treatment of the three wastes - waste water, waste gases and waste solids should be enhanced, as a result to reduce water pollution and to protect water resources.

(3) Water disinfection personnel should receive regular sanitation training, so that they can master water purification skills and disinfectant adding rules. Special attention should be given to the amount of chlorine added into drinking water. Chlorine disinfection is cheap, simple and with better disinfection result. Since the effects of chlorine disinfection of drinking water and CBPs on human health are not conclusive, currently chlorine disinfection is still the most widely used disinfection method for drinking water (Lin et al, 2002). However, it is not to say that the more chlorine the better. Epidemiological studies suggested that chlorine disinfection of drinking water was related to the incidence of and the death caused by cancer among multiple organs, in which bladder cancer, colon cancer, and rectal cancer had a strong and stable relation with chlorine disinfection (Chen et al, 2006).

(4) In water supply networks, high-quality PVC pipes should be used to transport drinking water, and any 
possible impacts of stress from roads above or from tillage should be avoided.

\section{References}

Chen, J., Xu, J. M., Liu, Y. et al. (2006). Drinking water quality surveillance in rural areas of Yuxi City. Occupation and Health, 22(21):1861-1862.

Health Law and Supervision Department. (2001). Ministry of Health, People's Republic of China. Sanitary Standards for Drinking Water, 2.

Health Law and Supervision Department. (2001). Ministry of Health, People's Republic of China. Standard Examination Methods for Drinking Water, 73.

Lin, H., Liu, J. P. \& Song, J. Y. (2002). Case-control study on relationship between exposure to chlorinated water and risk of bladder cancer. Chinese Journal of Public Health, 4(18):397-399.

Lu, H, \& Wang, Y. Q. (2009). Vulnerability assessment of groundwater in Tai'an City. Nonferrous Metals, 61(4):180-184.

Wang, B., Chen, L., \& Zhang, F.W. (2009). Study on degradation of groundwater environment and ecological safety methods. Water Resource Management, 21:42-44.

Table 1. Drinking water quality test results

\begin{tabular}{|c|c|c|c|c|c|c|}
\hline Indicator & $\begin{array}{c}\text { Total } \\
\text { number of } \\
\text { samples }\end{array}$ & $\begin{array}{l}\text { Number of } \\
\text { samples } \\
\text { exceeding } \\
\text { standards }\end{array}$ & $\begin{array}{l}\text { Exceeding } \\
\text { rate }(\%)\end{array}$ & $\begin{array}{l}\text { Measurement } \\
\text { range }\end{array}$ & $\begin{array}{l}\text { Sanitary } \\
\text { standard }\end{array}$ & $\begin{array}{c}\text { Maximum } \\
\text { measurement } \\
\text { exceeding ratio }\end{array}$ \\
\hline $\begin{array}{c}\text { Total } \\
\text { dissolved } \\
\text { solids }\end{array}$ & 96 & 0 & 0 & $1 \sim 56.7$ & $1000 \mathrm{mg} / \mathrm{L}$ & 0 \\
\hline Turbidity & 96 & 0 & 0 & $0.1 \sim 0.5$ & $5 \mathrm{NTU}$ & 0 \\
\hline Color & 96 & 0 & 0 & $3 \sim 12$ & $15 \mathrm{TCU}$ & 0 \\
\hline $\begin{array}{l}\text { Taste and } \\
\text { odor }\end{array}$ & 96 & 0 & 0 & None & $\begin{array}{l}\text { Without } \\
\text { abnormal taste } \\
\text { or odor }\end{array}$ & 0 \\
\hline $\mathrm{pH}$ & 96 & 0 & 0 & $6.5 \sim 7.0$ & $6.5 \sim 8.5$ & 0 \\
\hline $\begin{array}{c}\text { Total } \\
\text { hardness }\end{array}$ & 96 & 12 & 12.50 & $120 \sim 488$ & $450 \mathrm{mg} / \mathrm{L}$ & 1.08 \\
\hline Iron & 96 & 42 & 43.75 & $0.1 \sim 1.05$ & $0.3 \mathrm{mg} / \mathrm{L}$ & 3.5 \\
\hline $\begin{array}{l}\text { Volatile } \\
\text { phenol }\end{array}$ & 96 & 18 & 18.75 & $0.001 \sim 0.003$ & $0.002 \mathrm{mg} / \mathrm{L}$ & 1.5 \\
\hline Nitrate & 96 & 0 & 0 & $15.2 \sim 19.1$ & $20 \mathrm{mg} / \mathrm{L}$ & 0 \\
\hline $\begin{array}{l}\text { Ammonia } \\
\text { nitrogen }\end{array}$ & 96 & 72 & 75 & $0.21 \sim 0.86$ & $0.1 \mathrm{mg} / \mathrm{L}$ & 8.6 \\
\hline $\mathrm{Cr}(\mathrm{VI})$ & 96 & 24 & 25 & $0.045 \sim 0.064$ & $0.05 \mathrm{mg} / \mathrm{L}$ & 1.28 \\
\hline Fluoride & 96 & 0 & 0 & $0.12 \sim 1.0$ & $1.0 \mathrm{mg} / \mathrm{L}$ & 0 \\
\hline $\begin{array}{c}\text { Total } \\
\text { bacteria }\end{array}$ & 96 & 12 & 12.50 & $4 \sim 445$ & $100 \mathrm{CFU} / \mathrm{mL}$ & 4.45 \\
\hline $\begin{array}{c}\text { Total } \\
\text { coliform }\end{array}$ & 96 & 66 & 68.75 & $2 \sim 28$ & $\begin{array}{l}\text { Less than } 3 \text { in } \\
\text { every } 100 \mathrm{~mL} \text { of } \\
\text { water sample }\end{array}$ & 9.3 \\
\hline
\end{tabular}

